Jadwiga WIERZBICKA

Fish parasitology

\title{
PARASITIC PROTOZOA OF A GREENLAND HALIBUT REINHARDTIUS HIPP.OGLOSSOIDES (WALBAUM, 1792)
}

PASOŻYTNICZE PIERWOTNIAKI HALIBUTA NIEBIESKIIEGO,
REINHARDTIUS HIPPOGLOSSOIDES (WALBAUM, 1792)

Institute of Ichthyology Academy of Agriculture, Szczecin

\begin{abstract}
A detailed description of morphology of three protozoan species found in the gall bladder and urinary bladder of the Greenland halibut in given. The fishes were caught in the North Atlantic and the Pacific. Drawnings of spores and their dimensions are also given. One of the four found species is described for the first time in the Greenland halibut.
\end{abstract}

\section{INTRODUCTION}

So far, parasitic Protozoa of the Greenland halibut have been studied relatively rarely. Poljanskij (1955) mentioned them in this host from the Barents Sea. Wierzbicka (1987) mentioned parasites from this group off the Labrador. According to Sulman's (1966) elaboration the Greenland halibut is parasiting only by one species Ceratomyxa drepanopsettae. Lately Kovaleva's et al. (1983) paper has been published on protozoans of Myxoproteidae fam. nov. parasiting on marine fish. Among others species, the authors described a new genus and species-Schulmania quadriolobata found in the gall bladder of Reinhardtius hippoglossoides and Atheresthes evermani. The fish they investigated came from the Atlantic and the Pacific Ocean. In 1986 Wierzbicka also described a new genus and species-Paramyxoproteus reinhardti in the gall bladder of this host.

The protozoans discovered during my investigations of the Greenland halibut differ slightly morphologically from so far described and require further more precise descriptions or some supplements and comments. 


\section{MATERIAL AND METHODS}

The fish examined came mainly from the North Atlantic. Individuals from off the Labrador and the Barents Sea were caught on June ó.1976 and May 26.1977, respectively and frozen to below $-20 \mathrm{C}$ on board. 155 specimens of the Greenland halibut, Reinhardtius hippoglossoides (Walbaum, 1792) from off the Labrador were studied, and 106 specimens from the Barents Sea. The.total lenght (longitudo totalis) and weight of the fish examined were found to range within $24.2-77.5 \mathrm{~cm}$, and $75-5140 \mathrm{~g}$, respectively.

In addition seven Greenland halibute specimens from the North Pacific were examined. The North Pacific sample was obtained in spring 1981 from the eastern Bering Sea. Their total length (longitudo totalis) and weight ranged within $55.5-82.5 \mathrm{~cm}$ and $1530-6200 \mathrm{~g}$, respectively.

Skin, fins, nostrils, gall bladder, kidney and urinary bladder were examined. Muscles were checked for the presence of protozoans as well. When stronger infection was observed, parts or scrapes of infected organ and the content of gall bladder was preserved in $5 \%$ formalin for further study. Some observations referred to protozoans were also made on unstained samples (immediately after thawing). Spores were measured according to Sulman's $(1966,1984)$ outline. All measurements are given in micrometers.

\section{RESULTS}

In the examined specimens of the Greenland halibut were found to harbour four protozoan species belonging to the order Bivalvulida.

Ceratomyxa drepanopsettae, Awerinzew, 1908

Location in hos: gall bladder

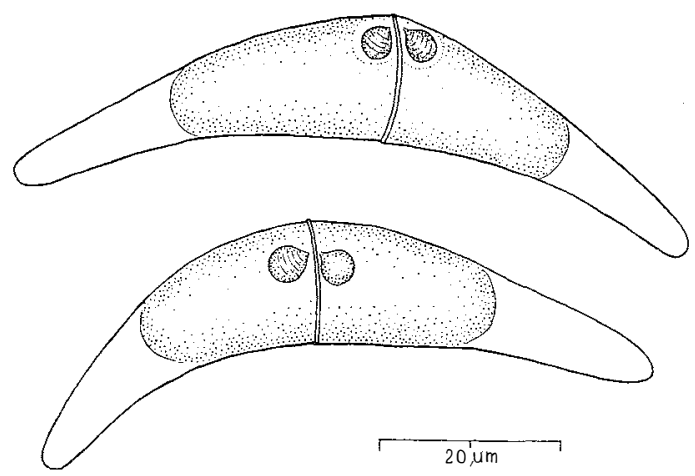

Fig. 1. Spores of Ceratomyxa drepanopsettee (from the Atlantio- off the Labrador) 
Only spores were found (Fig. 1,2,3). According to my observations spores are lightly arcuately curved and a little assymetrical in shape. The foremost margin of spore, by which lie polar capsules, is more curved than the posterior one. Ends of the spore are somewhat narrowed and bluntly pointed. The suture line-straight and rather well-visible, shell thin and delicate. Two polar capsules, almost spherical shaped with short narrowed

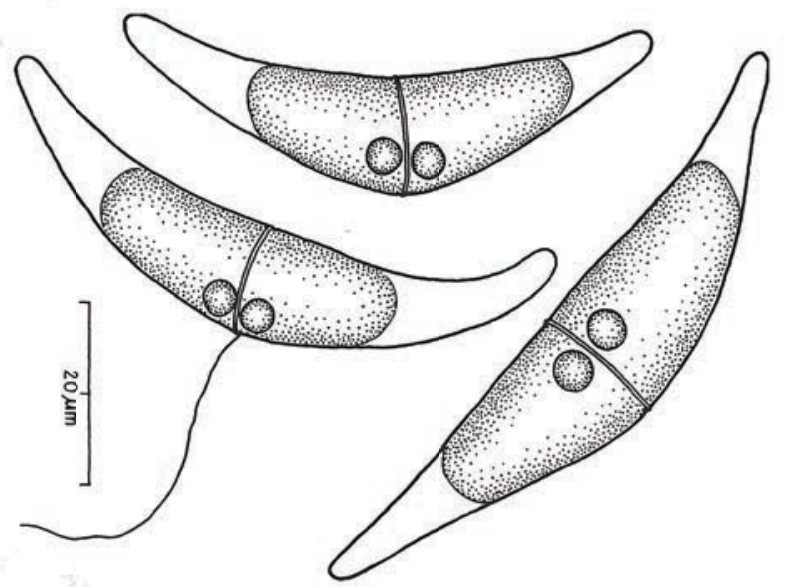

Fig. 2. Spores of Ceratomyxa depanopsettae (from the Pacific- the Bering Sea)

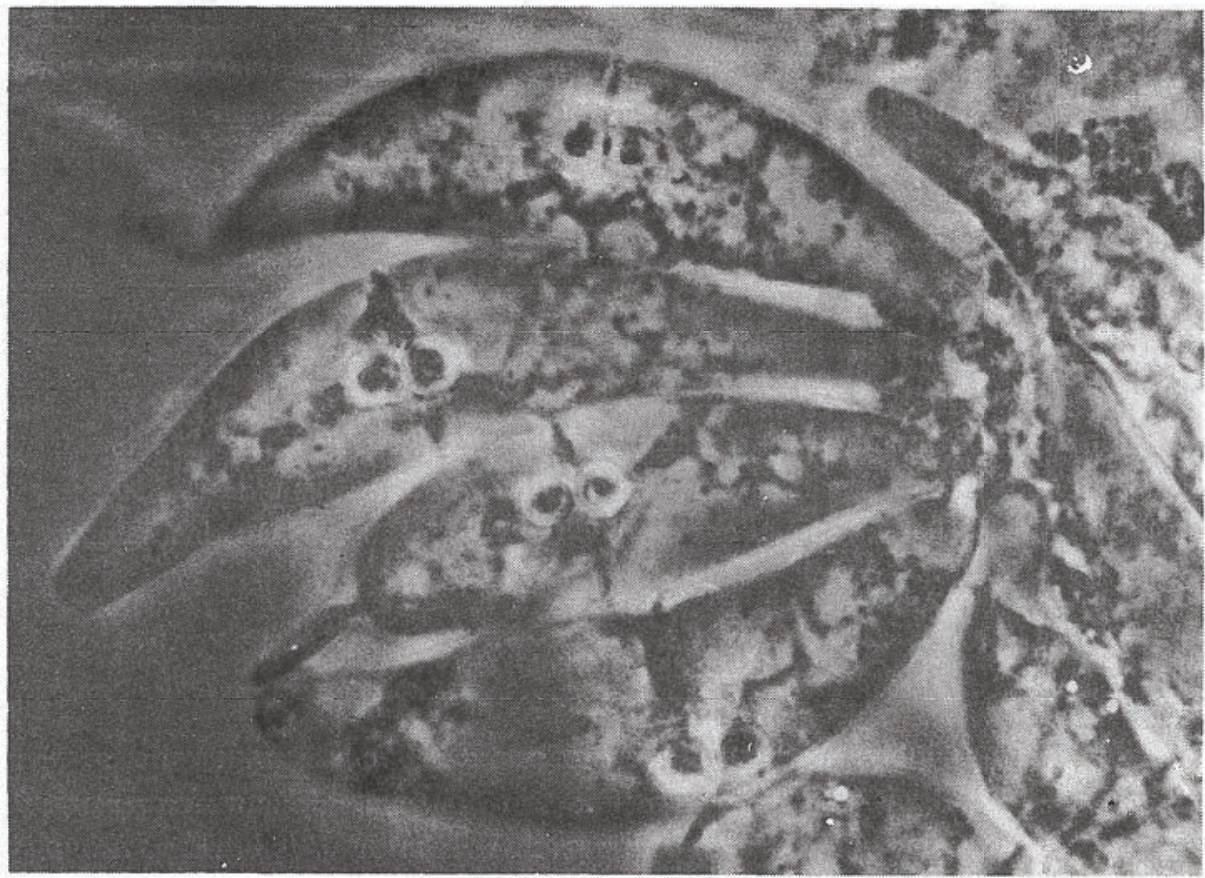

Fig. 3. Spores of Ceratomyxa drepanopsettae from fish hrevy infected (from the Barents Sea) 
outlet canals are situated close one to another, in the anterior part of spore, very close to suture line. The sporoplasm does not fill the narrowed ends of spore. A thin membrane can be seen in some spores, separating polar capsules from sporoplasm (Fig. 1).

Dimensions of spores (preserved sample)

Off the Labrador

(26 spores measured)

The Bering Sea

$12.4-15.0)(13.62 \pm 0.80) \mu^{*}$

(26 spores measured)

Lenght of spore

$56.0-79.0(69.71 \pm 5.72) \mu$

$12.0-13.2(12.57 \pm 0.51)$ us

Width of spore

Width of polar

capsules

$3.6-4.4(3.96 \pm 0.27) \mu$

$54.0-70.0(64.60 \pm 4.14) \mu$

$3.6-4.4(3.79 \pm 0.24) \mu$

Myxidium incurvatum Thélohan, 1892

Location in host: gall bladder

According to my observations the parasite spores are elongated, rather strongly s-shaped, with sharply pointed ends (Fig. 4). Margins of the spore between polar capsules
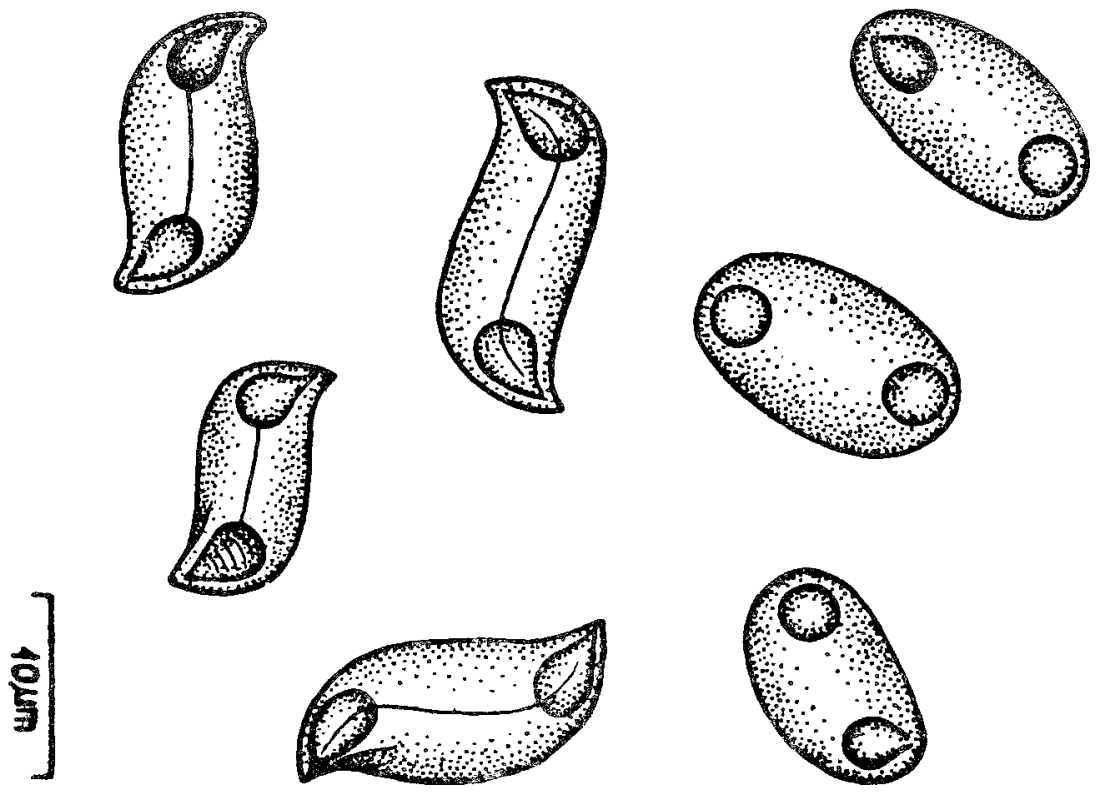

Fig. 4، Spores of Myxidium incurvatum (from the Atlantic-off the Labrador)

* Arithmetical mean and standard deviation of the sample are given in brackets, respectively. This explanation refers to all dimensions given. 
are parallel to each other. Polar capsules are pyriform, with sharply pointed ends. Suture line faint, extends parallel to the lateral margins, then turns to the narrowed ends of spore. Surface of the spore is smooth, without striae. The sporoplasm is placed between polar capsules.

Dimensions of spores (preserved sample)

Off the Labrador

(30 spores measured)

Lenght of spore

$12.0-16.8(14.47 \pm 1.23) \mu$

Width of spore

Thickness of spore

Lenght of polar

capsules

Width of polar

capsules

$$
7.2-8.8 \quad(8.23 \pm 0.41) \mu
$$$$
5.6-7.6 \quad(6.77 \pm 0.55) \mu
$$

$3.6-4.8 \quad(4.21 \pm 0.35) \mu$

$2.4-3.2(2.67 \pm 0.27) \mu$
The Bering Sea (22 spores measured) $13.6-16.4(15.07 \pm 0.99) \mu$ $7.6-8.8 \quad(8.16 \pm 0.40) \mu$ $7.2-8.0 \quad(7.54 \pm 0.36) \mu$

$4.0-4.8 \quad(4.45 \pm 0.28) \mu$

$2.4-3.2(2.75 \pm 0.25) \mu$

Ortholinea divergens (Thélohan, 1895)

Location in host: urinary bladder

The spores found in examined material are nearly spherical in the suture line plane, and flattened in the perpendicular plane (Fig. 5). The thickness of spore is much smaller
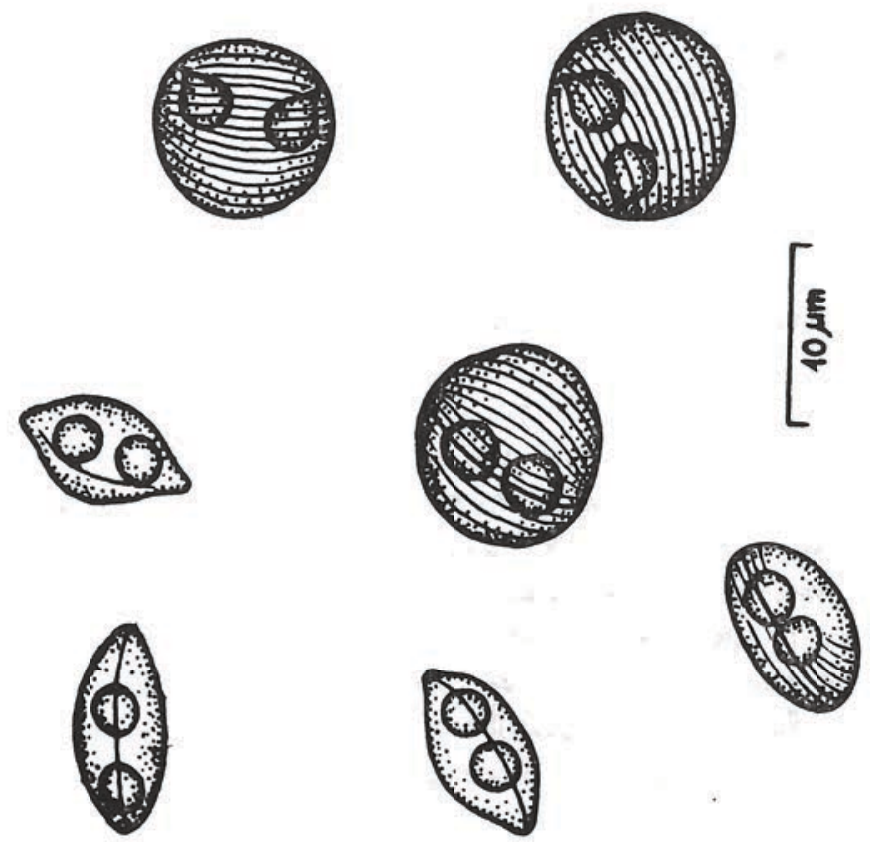

Fig. 5. Spores of Ortholinę divergens (from the Barents Sea, unpreserved sample) 
than the width. All surface is covered by subtle striae. Two pyriform-spherically shaped polar capsules are placed close to the frontal margin in the suture line plane. Polar capsules with short and sharply pointed outlets are situated in long distance from each other, nearly on opposite sides of spore. The sporoplasm is situated below polar capsules.

Dimensions of spores from the Barents Sea

(unpreserved sample,

Lenght of spore

Width of spore

Thickness of spore

Width of polar capsules

Lenght of polar filaments
$8.0-10.0(9.17 \pm 0.78) \mu$

$8.8-10.0(9.44 \pm 0.39) \mu$

$4.8-5.4(5.12 \pm 0.30) \mu$

about $20.0 \mu$ (preserved sample,

25 spores measured)

$8.0-8.8(8.34 \pm 0.36) \mu$

$8.0-9.2(8.37 \pm 0.34) \mu$

$4.8-6.8(5.90 \pm 0.57) \mu$

$2.4-3.2(2.62 \pm 0.26) \mu$

Vegetative stages of the three previous described species were difficult to identify since the examinations were made on frozen material.

Paramyxoproteus reinhardti Wierzbicka, 1986

Location in host: urinary bladder

The precise description of spores of this species and characterization of a new found genus Paramyxoproteus was given in Wierzbicka's (1986) work.

Above-mentioned protozoan species were frequent parasites of the Greenland halibut. They were observed, with the exception of Ortholinea divergens, in all studied areas. This species was not found in individuals from the Bering Sea only.

\section{DISCUSSION}

The previous available works described two protozoan species of the genus Ceratomyxa in the gall bladder of the Greenland halibut. Ceratomyxa drepanopset tae has been the most frequently described species (Poljanskij 1955, Sulman 1966, Zubchenko 1980). The second species C. ramosa Awerinzew, 1907 is rather typical for the whits halibut only (Kudo 1919, Sulman 1966). C. ramosa existing in the Greenland halibut was mentioned only by Zubchenko (1980). Presently found spores in specimens of the Greenland halibut from the Bering. Sea, the Barents Sea and off the Labrador do not differ essentially from described earlier. The spores were most similar in dimensions and morphology to this of C. drepanopsettae. However hitherto descriptions are not very precise. The drawings by Kudo (1919) and Sulman (1966) describe the spores with distinctly elongated, pyriform polar capsules, while in examined material polar capsules were always almost spherical (Fig. 1, 2, 3).

The next parasite, Myxidium sphaericum Thélohan, 1895 was mentioned by Zubchenko (1980) in the gall bladder of the Greenland halibut from the North-West 
Atlantic. However the author didn't affix neither deseription nor drawnings of the found sporozoan. Earlier, these protozoans were observed only in fish of the genus Belone (Kudo 1919, Pogorelceva 1964, Sulman 1966). Present study based on a large amount of examined specimens, has showed occurence of the different species.-M.incurvatum (Fig. 4). This species differs completely from the former with the shape of spore. Protozoans $M$. incurvatum are common parasites of many marine fishes, flatfish among them (Kudo 1919, Pogorelceva 1964, Sulman 1966). Presently this species has been described in the Greenland halibut for the first time.

Ortholinea divergens has been found in the urinary bladder of examined fishes. Zubchenko (1980) mentioned this species also in the Greenland halibut. Comparing morphology of the found spores with those previous described (Kudo 1919, Sulman 1966) some differences in the shape of polar capsules were observed. The former authors maintain that polar capsules are pyriform (considerably elongated). According to own observations they appeared to be pyriform-spherical-shaped (Fig. 5). Moreover, the thickness of spores is a litle smaller $(4.8-6.8 \mu \mathrm{m})$ than this described in pre-cited literature $(8.0 \mu \mathrm{m})$. According to Moser and Noble (1977) the thickness of spores ranged from 6.5 to $8.0 \mu \mathrm{m}$. The authors found this protozoan in the gall bladder of Coelorhynchus coelorhynchus carminatus (Macrouridae). It has been described only in renal tubules and the urinary bladder.

There are known two others sporozoan species parasiting on the urinary bladder of the Greenland halibut. The first-Schulmania quadriolobata was described as a new genus and species by Kovaleva et al. (1983), the second-Paramyxoproteus reinhardti by this article author. Features distinguishing these two protozoans were given in Wierzbicka (1986). It's suprising however that in relatively great studied material, spores morphologically adequate to these described as $S$. quadrolobata have not been found. Whereas spores described as $P$. reinhardti have been observed very often.

\section{REFERENCES}

Kovaleva A.A., ZubCenko A.V., Krasin V.K., 1983: Obosnovanie novogo semejstva miksosporidij (Protozoa, Myxosporidia) s opisaniem dwuh novyh rodov. - Parazitologija, 17, 3: 195-202 (in Russian).

Kudo R, 1919: Studies on Myxosporidia A synopsis of genera and species of Myxosporidia. - Ill. Biol. Monogr., 5: 245-503.

Moser M., Noble E.R., 1977: Myxosporidan genera Auerbachia, Sphaerosopora, Davisia and Chloromyxum in macrourid fishes and the sablefish, Anoplopoma fimbria。 - Z. Parasitenk, 51 (2): 159-163.

Pogorelceva T.P., 1964: Materialy k ỉzuð̌eniju parazitið̌eskih prostejših ryb Cemogo morja. - Probl. Parazitol., Trudy Ukrainsk. respubl. naǔ̌n. obšc. Parazitol., 3: 16-29. (in Russian).

Poljanskij Ju.I., 1955: Materialy po parazitologii ryb severnyh morej SSSR. Parazity ryb Barencova morja. - Trudy Zool. Inst. AN SSSR, 19: 5-170 (in Russian).

Sulman S.S., 1966: Miksosporidii fauny SSSR. - Izd. "Nauka", Moskva - Leningrad (in Russian). 
Sulman S.S. (ed.), 1984: Opredelitel parazitov presnovodnyh ryb fauny SSSR. I. Parazitiðeskie prostejßie. - Izd. „Nauka”, Leningrad (in Russian).

Wierzbicka J., 1986: Paramyxoproteus reinhardti gen. n. et sp.n. (Bivalvulida, Myxospora), a parasite of Reinhardtius hippoglossoides (Walbum, 1792). - Acta Protozool., 25 (2): 227-234.

Wierzbicka J., 1987: Fauna pasożytnicza halibuta niebieskiege, Reinhardtius hippoglossoides (Walbum) $\mathrm{z}$ łowisk Labradoru. - [The parasitic fauna of a Greenland halibut, Reinhardtius hippoglossoides (Walbaum) from the fisheries off the Labrador]. Streszczenia materiałów zjazdowych, XV Zjazd Pol. Tow. Parazytol., Katowice, 24-26.IX.1987: 133.

Zubchenko A.V., 1980: Parasitic fauna of Anarhichadidae and Pleuronectidae families of fish in the Northwest Atlantic. - Int. Commis. Northwest Atlant. Fish., Selec. Pap., 6: 41-46 (in Russian).

Translated: D. Romuk-Wodoracki

Jadwiga Wierzbicka

\section{PASOŻYTNICZE PIERWOTNIAKI HALIBUTA NIEBIESKIEGO, REINHARDTIUS HIPPOGLOSSOIDES (WALBUM, 1792)}

\section{STRESZCZENIE}

Badane ryby pochodziły z północnego Atlantyku (łowisko Labradoru i Morze Barentsa) oraz z północnego Pacyfiku (Morze Beringa). Łącznie zbadano 268 osobników halibuta niebieskiego. W materiale tym znaleziono cztery. gatunki pierwotniaków. Należały one do rzędu Bivalvulida. Stwierdzone pasożyty występowały w woreczku żółciowym lub w pęcherzu moczowym.

W pracy podano szczegółowy opis morfologiczny trzech znalezionych gatunków pierwotniaków. Zamieszczono także wymiary i rysunki spor tych pasożytów.

Po raz pierwszy stwierdzono występowanie w halibucie niebieskim pierwotniaka Myxidium incurvatum.

Authors address:

Received: 1990.01 .19

Doc. dr hab. Jadwiga Wierzbicka

Instytut Ichtiologii

ul. Kazimierza Królewicza 4

71-550 Szczecin

Polska (Poland) 